\title{
Protective role of +294 T/C (rs2016520) polymorphism of $P P A R D$ in Mexican patients with colorectal cancer
}

\author{
M.A. Rosales-Reynoso ${ }^{1}$, L.I. Wence-Chavez ${ }^{1}$, A.R. Arredondo-Valdez ${ }^{1}$, \\ S. Dumois-Petersen ${ }^{1}$, P. Barros-Núñez ${ }^{2}$, M.P. Gallegos-Arreola ${ }^{1}$, \\ S.E. Flores-Martínez ${ }^{1}$ and J. Sánchez-Corona ${ }^{1}$
}

${ }^{1}$ División de Medicina Molecular, Centro de Investigación Biomédica de Occidente, Centro Médico Nacional de Occidente, Instituto Mexicano del Seguro Social, Guadalajara, Jalisco, México

${ }^{2}$ División de Genética, Centro de Investigación Biomédica de Occidente, Centro Médico Nacional de Occidente, Instituto Mexicano del Seguro Social, Guadalajara, Jalisco, México

Corresponding author: M.A. Rosales-Reynoso

E-mail: mareynoso77@yahoo.com.mx / monica.rosales@imss.gob.mx

Genet. Mol. Res. 16 (1): gmr16019324

Received September 20, 2016

Accepted November 16, 2016

Published January 23, 2017

DOI http://dx.doi.org/10.4238/gmr16019324

Copyright $(2017$ The Authors. This is an open-access article distributed under the terms of the Creative Commons Attribution ShareAlike (CC BY-SA) 4.0 License.

ABSTRACT. PPARD encodes for peroxisome proliferator-activated receptor delta, which plays a significant role in controlling lipid metabolism, atherosclerosis, inflammation, cancer growth, progression, and apoptosis. Accumulated evidence suggests that the polymorphism rs2016520 in PPARD is associated with lipid metabolism, obesity, metabolic syndrome, and type 2 diabetes mellitus. The aim of this study was to determine whether the single nucleotide polymorphism $+294 \mathrm{~T} / \mathrm{C}$ (rs2016520) in PPARD is associated with colorectal cancer (CRC) in the Mexican population. Genomic DNA from 178 CRC 
patients and 97 healthy blood donors was analyzed. The polymorphism was identified by the polymerase chain reaction-restriction fragment length polymorphism method. Results demonstrated that patients with the T/C genotype for the $+294 \mathrm{~T} / \mathrm{C}$ (rs2016520) polymorphism present a protective role against $\mathrm{CRC}$ [odds ratio $(\mathrm{OR})=0.39 ; 95 \%$ confidence interval $(\mathrm{CI})=0.22-0.69 ; \mathrm{P}=0.0008]$. This association was also evident for the $\mathrm{T} / \mathrm{C}$ genotype in the stratified analysis by tumor-nodemetastasis stages $\mathrm{I}+\mathrm{II}(\mathrm{OR}=0.26, \mathrm{P}=0.0332)$ and $\mathrm{III}+\mathrm{IV}(\mathrm{OR}=0.44$, $\mathrm{P}=0.0067)$. However, in the stratified analysis by tumor location, we observed an increased risk of rectal cancer $(\mathrm{OR}=7.57, \mathrm{P}=0.0403)$ $v s$ colon cancer $(\mathrm{OR}=4.87, \mathrm{P}=0.234)$ in patients carrying the $\mathrm{C} / \mathrm{C}$ genotype and under the dominant and recessive models of inheritance. In conclusion, for the first time, the association between the +294T/C (rs2016520) polymorphism and colorectal cancer has been studied in Mexican patients. Our results reveal that variations in PPARD may play a significant role in genetic susceptibility to colorectal cancer.

Key words: PPARD; rs2016520 polymorphism; Colorectal cancer; TNM staging; Mexican population

\section{INTRODUCTION}

Colorectal cancer (CRC), at present, is one of the most common causes of cancer mortality, ranking second in females, third in males, and fourth in the world. Furthermore, the rate of incidence of CRC is on the rise worldwide (Jemal et al., 2011). The pathogenesis of CRC is complex and still not fully understood. However, it has been reported that genetic susceptibility to CRC is associated with genes related to cell proliferation, differentiation, and transformation, causing failure of apoptosis and abnormalities in multiple signaling pathways (Fearon and Vogelstein, 1990; Ticha et al., 2013; Wang et al., 2014).

The Wnt/ $\beta$-catenin pathway has been associated with colon cancer since it was reported that abnormalities in the chromosome $5 \mathrm{q}$ are early events in the tumorigenic processes of sporadic and hereditary (familial adenomatous polyposis, FAP) tumors and that FAP resides at this chromosomal location (Arnold et al., 2005; Markowitz and Bertagnolli, 2009). Mutations in genes involved in the Wnt signaling pathway, most of which inhibit the APC (adenomatous polyposis coli) function, are found in close to $90 \%$ of sporadic colon cancers (Markowitz and Bertagnolli, 2009). Activation of Wnt $/ \beta$-catenin target genes depends on the recruitment of $\beta$-catenin into the nucleus. TCF7L2 forms a protein complex with the lymphoid factor 1 . Interaction of LEF/TCF with the $\beta$-catenin protein results in the formation of a transcription complex that regulates the expression of target genes participating in colorectal carcinogenesis, such as CCND1, PPARD, and c-Myc (He et al., 1999; Krausova and Korinek, 2014; Rennoll and Yochum, 2015). He et al. (1999) identified the peroxisome proliferator-activated receptor $\delta(P P A R D)$ gene as a target of APC through the analysis of global gene expression profiles in human colorectal cancer cell lines (He et al., 1999). Consequently, considerable attention has been given to the role of PPARD in CRC development. PPARD encodes for a ligandactivated transcription factor that belongs to the nuclear hormone receptor superfamily. This gene has nine exons, five of which are coding, and spans around $85 \mathrm{~kb}$ of the region $6 \mathrm{p} 21.2$

Genetics and Molecular Research 16 (1): gmr16019324 
(Skogsberg et al., 2003a,b). PPARD is expressed in diverse tissues with very high expression levels in the gastrointestinal tract (Park et al., 2001; Barak et al., 2002; Lee et al., 2003; Gupta et al., 2004; Harman et al., 2004; Foreman et al., 2011; Peters et al., 2011; Yang et al., 2006, 2008, 2010, 2011; Fucci et al., 2012; Wang et al., 2006, 2014; Zuo et al., 2009, 2014). Several PPARD polymorphisms have been involved in regulation of lipid and glucose metabolism and in disorders related to these processes, including cardiovascular disease (Skogsberg et al., 2003a,b), atherosclerosis (Chen et al., 2004), insulin resistance (Hu et al., 2006), diabetes (Villegas et al., 2011), and recently in cancer (Ticha et al., 2013; Yang et al., 2014). Notably, the PPARD $+294 \mathrm{~T} / \mathrm{C}$ (rs2016520) polymorphism, which is located in exon 4 at 87 nucleotides upstream of the start codon (5' untranslated region), influences the binding of Sp1 transcription factor resulting in higher transcriptional activity when the rare $\mathrm{C}$ allele is present (Skogsberg et al., 2003a). This suggests that Sp1 acts together with another, yet unidentified, factor in the allelespecific regulation of PPARD (Skogsberg et al., 2003b). Sp1 is a member of the gene family with sequence-specific DNA-binding C-terminal zinc-finger motifs. It plays a critical role in the regulation of expression of mammalian genes lacking a TATA box by binding to GC/GT boxes to activate transcription (Raynaud et al., 2008; Dong et al., 2009). It has been reported that Sp1 is involved in the development and progression of several types of cancers, including colorectal cancer (Dong et al., 2009). At present, CCND1, PDEGF, p21, VEGF, TGF $\beta$, E2F1, c-fos, OPN, and TGF $\alpha$ are the cancer-related Sp1 targets that have been identified (Gartel et al., 2000; Zhu et al., 2002; Takami et al., 2007; Dong et al., 2009). There has been one study on the association of PPARD gene variants with upper aero-digestive tract cancers in patients from Los Angeles, CA, USA (Yang et al., 2014) and another on their association with colorectal cancer in patients from Switzerland (Ticha et al., 2013). However, no association of the +294 T/C (rs2016520) polymorphism with colorectal cancer development was found in patients from Sweden (Ticha et al., 2013). To our knowledge, this is the first report on the association between the PPARD gene polymorphism $+294 \mathrm{~T} / \mathrm{C}$ (rs2016520) and colorectal cancer in Mexican patients.

\section{MATERIAL AND METHODS}

\section{Study population}

The study included 178 individuals (83 females and 95 males) diagnosed with colorectal adenocarcinomas according to the clinicopathological criteria of Specialty Hospital in Centro Medico Nacional of Instituto Mexicano del Seguro Social (IMSS) in Guadalajara, Jalisco, México. CRC diagnosis was established according to the tumor-node-metastasis (TNM) classification. The control group consisted of 97 healthy volunteers ( 32 females and 65 males). These volunteers did not match in age with the patient group. All the subjects included in this study, between 2012 and 2014, were from the metropolitan area of Guadalajara. Signed informed consent forms were obtained from all study participants. We used a standard epidemiological questionnaire to collect personal data, including age, gender, family history, drinking, and smoking status. Individuals with a previous history of cancer were excluded from the control group, while those who had undergone chemotherapy or radiotherapy were excluded from the patient group in the study. Information about the clinical and pathological characteristics of the patients was obtained from hospital records. This study was approved by the Ethical Committee 1305 (R-2012-1305-10) of Centro de Investigación Biomédica de Occidente, IMSS. This study was conducted by adhering to national and international ethical standards.

Genetics and Molecular Research 16 (1): gmr16019324 


\section{Genotyping}

Genomic DNA was extracted from peripheral blood using standard methods (Miller et al., 1988). The polymorphism $+294 \mathrm{~T} / \mathrm{C}$ (rs2016520) in PPARD was genotyped by the polymerase chain reaction-restriction fragment length polymorphism (PCR-RFLP) method, using the primers: +294-F: 5'-CATGGTATAGCACTGCAGGAA-3' and +294-R: 5'-CTTCCTCCTGTGGTCGCTC-3' (Skogsberg et al., 2003a). PCR was performed for 30 cycles and with a total volume of $10 \mu \mathrm{L}$ containing $100 \mathrm{ng}$ DNA, $10 \mathrm{X}$ buffer $(500 \mathrm{mM} \mathrm{KCl}$, $100 \mathrm{mM}$ Tris- $\mathrm{HCl}$, and $0.1 \%$ Triton TMX-100), $2.0 \mathrm{mM} \mathrm{MgCl}, 200 \mu \mathrm{M}$ dNTPs, 1 pM each primer, and $1 \mathrm{U}$ Taq DNA Polymerase. Denaturation was carried out at $95^{\circ} \mathrm{C}$, annealing at $62^{\circ} \mathrm{C}$, and elongation at $72^{\circ} \mathrm{C}$ for 1 min each. Five microliters of the PCR products were digested with $3 \mathrm{U} B s l \mathrm{I}$ enzyme, according to the manufacturer instructions. The digested products were separated on $6 \%$ polyacrylamide gels (Figure 1). Bands observed by electrophoresis corresponded to 167 and $102 \mathrm{bp}$ for the polymorphic allele (C) and $269 \mathrm{bp}$ for the wildtype allele (T). Quality control for these assays was performed by randomly selecting several samples that were re-genotyped by an independent technician. The observed concordance between genotyping assays was $100 \%$.

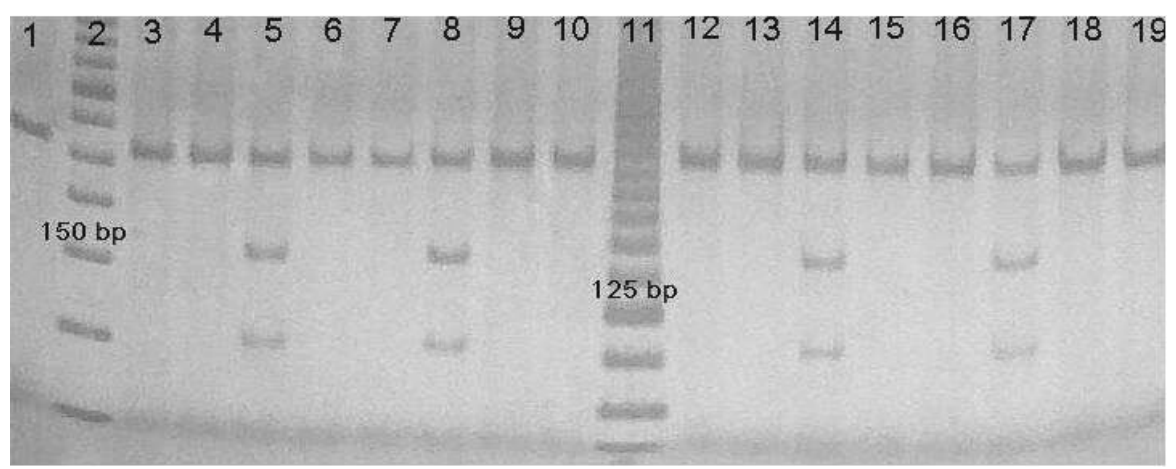

Figure 1. Polyacrylamide gel (6\%) dyed with $\mathrm{AgNO}_{3}$. The gel represents the results of the enzymatic digestion procedure with $B s I I$ enzyme, performed to identify the genotypes for the rs 2016520 polymorphism in PPARD. Lane $2=50$-bp molecular marker. Lane $11=25$-bp molecular marker. Lanes 1, 3, 4, 6, 7, 9, 10,12, 13, 15, 16, 18, and 19 $=$ fragment of $269 \mathrm{bp}$ corresponding to the T/T genotype (wild homozygous). Lanes $5,8,14$, and $17=$ fragments of $269+167+102 \mathrm{bp}$ corresponding to the $\mathrm{T} / \mathrm{C}$ genotype (heterozygous).

\section{Statistical analysis}

Allele and genotype frequencies were estimated by direct counting in both groups. Hardy-Weinberg equilibrium (HWE) was assessed by the chi-square test. Differences in allele and genotype distribution between patients and controls were established by the chi-square test or the Fisher exact test. To evaluate the association of CRC with the presence of genotypes, the odds ratio (OR) and corresponding 95\% confidence intervals (CI) were calculated using the SPSS v17.0 software package (SPSS, Inc., Chicago, IL, USA). For all statistical analysis, $\mathrm{P}<$ 0.05 was considered statistically significant. 


\section{RESULTS}

Table 1 shows epidemiological and clinical data for the CRC patients and controls. There were no significant differences between the controls and CRC patients concerning gender, smoking status, and drinking status. We observed important differences in age distribution between the case and control groups $(\mathrm{P}=0.0001)$. In the $\mathrm{CRC}$ group, the observed average age was 59.03 years (ranging from 18 to 91 years); in contrast, in the control group, the observed average age was 36.88 years (ranging from 29 to 59 years).

Table 1. Epidemiological characteristics of the patients and controls in this study.

\begin{tabular}{|c|c|c|c|}
\hline \multirow[t]{2}{*}{ Mean Age (years) } & CRC patient group $(\mathrm{N}=178)$ & Control group $(\mathrm{N}=97)$ & $P$ value \\
\hline & 59.03 & 36.88 & 0.0001 \\
\hline \multicolumn{4}{|l|}{ Gender } \\
\hline Female & $88(49.44 \%)$ & $50(51.55 \%)$ & \multirow[t]{2}{*}{0.7383} \\
\hline Male & $90(50.56 \%)$ & $47(48.45 \%)$ & \\
\hline \multicolumn{4}{|l|}{ Drinking status } \\
\hline Have ingested alcoholic drinks & $65(36.52 \%)$ & $32(32.99 \%)$ & \multirow[t]{2}{*}{0.5148} \\
\hline Never ingested alcoholic drinks & $111(62.36 \%)$ & $65(67.01 \%)$ & \\
\hline NA & $2(1.12 \%)$ & & \\
\hline \multicolumn{4}{|l|}{ Smoking status } \\
\hline Smokers & $54(30.34 \%)$ & $24(24.74 \%)$ & \multirow[t]{2}{*}{0.2855} \\
\hline Non-smokers & $121(67.98 \%)$ & $73(75.26 \%)$ & \\
\hline NA & $3(1.68 \%)$ & & \\
\hline \multicolumn{4}{|l|}{ Family history of cancer } \\
\hline Yes & $30(16.85 \%)$ & - & \\
\hline No & $125(70.23 \%)$ & - & \\
\hline NA & $23(12.92 \%)$ & & \\
\hline \multicolumn{4}{|l|}{ Tumor localization } \\
\hline Colon & $80(44.94 \%)$ & - & \\
\hline Rectum & $18(10.12 \%)$ & - & \\
\hline NA & $80(44.94 \%)$ & & \\
\hline \multicolumn{4}{|l|}{ Clinical TNM stages } \\
\hline I-II & $25(14.04 \%)$ & - & \\
\hline III-IV & $131(73.60 \%)$ & - & \\
\hline NA & $22(12.36 \%)$ & & \\
\hline
\end{tabular}

$\mathrm{TNM}=$ tumor-node-metastasis; $\mathrm{NA}=$ not available; $\mathrm{CRC}=$ colorectal cancer; $\mathrm{P}$ values were calculated by the chisquare test.

Table 2 shows the genotype and allele frequencies of the PPARD +294 T/C (rs2016520) polymorphism. For the control group, the HWE was calculated, and the results for the SNP rs2016520 were in equilibrium (data not shown). The genotype $\mathrm{C} / \mathrm{C}$ of the rs2016520 polymorphism was observed in $6.74 \%(12 / 178)$ of the CRC patients and $3.09 \%(3 / 97)$ of the controls; this difference was not statistically significant. The genotype T/C was observed in 23.03\% (41/178) of the CRC patients and $44.33 \%(43 / 97)$ of the controls; this difference was statistically significant with an OR of 0.39 (95\%CI $=$ $0.22-0.69, \mathrm{P}=0.0008)$. We observed statistically significant results with an OR of 0.54 in the distribution of allele frequencies $(95 \% \mathrm{CI}=0.34-0.86, \mathrm{P}=0.0055)$. The risk analysis showed a decreased cancer risk under the dominant and overdominant inheritance patterns of allelic interactions with an $\mathrm{OR}$ of $0.47(95 \% \mathrm{CI}=0.27-0.81, \mathrm{P}=0.0035)$ and 0.38 $(95 \% \mathrm{CI}=0.21-0.66, \mathrm{P}=0.002)$, respectively. 
Table 2. Genotype and allele frequencies of the $+294 \mathrm{~T} / \mathrm{C}$ (rs2016520) polymorphism in PPARD in the patient and control groups.

\begin{tabular}{l|c|c|c|c}
\hline \multirow{2}{*}{ Genotype } & \multicolumn{2}{|c|}{ Frequencies } & OR $(95 \% \mathrm{CI})$ & P value \\
\cline { 2 - 3 } & $\begin{array}{r}\text { Patient group } \\
{[\mathrm{N}=178(\%)]}\end{array}$ & $\begin{array}{c}\text { Control group } \\
{[\mathrm{N}=97(\%)]}\end{array}$ & \\
\hline $\mathrm{T} / \mathrm{T}$ & $125(70.23)$ & $51(52.58)$ & 1.00 (Reference) & \\
\hline $\mathrm{T} / \mathrm{C}$ & $41(23.03)$ & $43(44.33)$ & $0.39(0.22-0.69)$ & 0.0008 \\
\hline $\mathrm{C} / \mathrm{C}$ & $12(6.74)$ & $3(3.09)$ & $1.63(0.40-7.63)$ & 0.6581 \\
\hline $\mathrm{C} / \mathrm{C}+\mathrm{T} / \mathrm{C}$ vs $\mathrm{T} / \mathrm{T}$ & $53(29.78)$ & $46(47.42)$ & $0.47(0.27-0.81)$ & 0.0035 \\
\hline $\mathrm{T} / \mathrm{T}+\mathrm{T} / \mathrm{C} v$ C $/ \mathrm{C}$ & $166(93.26)$ & $94(96.91)$ & $2.27(0.58-10.39)$ & 0.2037 \\
\hline $\mathrm{T} / \mathrm{T}+\mathrm{C} / \mathrm{C} v$ s $\mathrm{T} / \mathrm{C}$ & $137(76.97)$ & $54(55.67)$ & $0.38(0.21-0.66)$ & 0.0002 \\
\hline Allele & & & & \\
\hline $\mathrm{T}$ & $250(0.81)$ & $102(0.74)$ & $1.00($ Reference) & \\
\hline $\mathrm{C}$ & $65(0.19)$ & $49(0.26)$ & $0.54(0.34-0.86)$ & 0.0055 \\
\hline
\end{tabular}

$\mathrm{OR}=$ odds ratio; $\mathrm{CI}=$ confidence interval; $\mathrm{P}$ values were calculated by the chi-square test. Numbers in bold represent the results that showed statistical significance.

Analysis of the rs2016520 polymorphism by TNM staging is shown in Table 3 . We divided the colorectal cancer patients into two groups according to their TNM statuses. The association among the TNM groups and the rs2016520 polymorphism was not under a single pattern of allelic interactions by OR analysis (data not shown). However, when the two groups of TNM staging were compared with the control group, we observed a decreased risk of cancer in patients with the rs $2016520 \mathrm{~T} / \mathrm{C}$ genotype for stages I+II and III $+\mathrm{IV}(\mathrm{OR}=0.26,95 \% \mathrm{CI}=$ $0.07-0.92$, and $\mathrm{P}=0.0332$; and $\mathrm{OR}=0.44,95 \% \mathrm{CI}=0.24-0.81$, and $\mathrm{P}=0.0067$, respectively). We also found a decreased cancer risk under an over-dominant model for the stages I+II with an $\mathrm{OR}$ of $4.18(95 \% \mathrm{CI}=1.23-15.6, \mathrm{P}=0.0180)$ and under dominant and over-dominant models for the stages III+IV with an OR of $2.59(95 \% \mathrm{CI}=1.24-5.42, \mathrm{P}=0.0092)$ and 2.36 $(95 \% \mathrm{CI}=1.30-4.32, \mathrm{P}=0.0038)$, respectively.

Table 3. Association analysis of TNM stages with the distribution of genotypes for the $+294 \mathrm{~T} / \mathrm{C}$ (rs2016520) polymorphism of PPARD.

\begin{tabular}{l|c|c|c|c|c|c|c|c|c}
\hline Genotypes & $\begin{array}{c}\text { Stage I+II } \\
\text { CRC patients } \\
{[\mathrm{N}=25(\%)]}\end{array}$ & $\begin{array}{c}\text { Stage III+IV } \\
\text { CRC patients } \\
{[\mathrm{N}=131(\%)]}\end{array}$ & $\begin{array}{c}\text { Stage I+II vs } \\
\text { Stage III+IV } \\
\text { OR }(95 \% \mathrm{CI})\end{array}$ & P value & $\begin{array}{c}\text { Controls } \\
{[\mathrm{N}=97(\%)]}\end{array}$ & $\begin{array}{c}\text { Stage I+II CRC } \\
\text { vs Controls } \\
\text { OR (95\%CI) }\end{array}$ & $\begin{array}{c}\text { P value } \\
\text { Stage III+IV CRC } \\
\text { vs Controls } \\
\text { OR (95\%CI) }\end{array}$ & $\begin{array}{c}\text { P value } \\
1 \text { (Reference) }\end{array}$ \\
\hline $\mathrm{T} / \mathrm{T}$ & $18(72)$ & $89(67.94)$ & 1 Reference) & & $51(52.58)$ & 1 (Reference) & $1($ Reference) & \\
\hline $\mathrm{T} / \mathrm{C}$ & $4(16)$ & $33(25.19)$ & $1.67(0.48-6.32)$ & 0.5411 & $43(44.33)$ & $0.26(0.07-0.92)$ & $0.0332^{*}$ & $0.44(0.24-0.81)$ & $0.0067^{*}$ \\
\hline $\mathrm{C} / \mathrm{C}$ & $3(12)$ & $9(6.87)$ & $0.61(0.13-3.16)$ & 0.0601 & $3(3.09)$ & $2.83(0.41-19.9)$ & 0.4369 & $1.72(0.40-8.43)$ & 0.6314 \\
\hline Dom & $7(28)$ & $42(32.06)$ & $1.21(0.43-3.49)$ & 0.8683 & $46(47.42)$ & $0.43(0.15-1.22)$ & 0.1283 & $2.59(1.24-5.42)$ & $0.0092^{*}$ \\
\hline Rec & $22(88)$ & $122(93.13)$ & $1.85(0.36-8.35)$ & 0.6365 & $94(96.91)$ & $0.23(0.03-1.58)$ & 0.1875 & $0.43(0.09-1.81)$ & 0.3355 \\
\hline Over-Dom & $21(84)$ & $98(74.81)$ & $0.57(0.15-1.92)$ & 0.4632 & $54(55.67)$ & $4.18(1.23-15.6)$ & $0.0180^{*}$ & $2.36(1.30-4.32)$ & $0.0038^{*}$ \\
\hline
\end{tabular}

$\mathrm{CRC}=$ colorectal cancer; $\mathrm{OR}=$ odds ratio; $\mathrm{CI}=$ confidence intervals; Dom $=$ dominant model; $\mathrm{Rec}=$ recessive model; Over-Dom = over-dominant model; P values were calculated by the chi-square test. ${ }^{*}$ Significant $\mathrm{P}$ values.

Analysis of the rs2016520 polymorphism by tumor location is shown in Table 4 . Our stratified analysis revealed an increased cancer risk, with a statistical significance for colon and rectal cancers for patients carrying the homozygous $\mathrm{C} / \mathrm{C}$ genotype, with an OR of $4.87(95 \% \mathrm{CI}=1.19-19.80, \mathrm{P}=0.0234)$ and $7.57(95 \% \mathrm{CI}=1.27-45.07, \mathrm{P}=0.0403)$, respectively. Additionally, we observed a significantly increased cancer risk under the dominant model of inheritance for colon cancers with an $\mathrm{OR}$ of $1.98(95 \% \mathrm{CI}=1.08-3.61$, $\mathrm{P}=0.0347)$ and under the recessive model of inheritance for rectal cancers with an OR of $6.46(95 \% \mathrm{CI}=1.19-35.05, \mathrm{P}=0.0449)$.

Genetics and Molecular Research 16 (1): gmr16019324 
Table 4. Association analysis of PPARD +294 T/C (rs2016520) genotypes by tumor location.

\begin{tabular}{|c|c|c|c|c|c|c|c|}
\hline Genotype & $\begin{array}{c}\text { Controls } \\
{[\mathrm{N}=97(\%)]}\end{array}$ & $\begin{array}{l}\text { Colon cancer } \\
{[\mathrm{N}=80(\%)]}\end{array}$ & $\begin{array}{l}\text { Rectal cancer } \\
{[\mathrm{N}=18(\%)]}\end{array}$ & $\begin{array}{c}\text { Colon cancer } v s \text { controls } \\
\text { OR }(95 \% \mathrm{CI})\end{array}$ & $P$ value & $\begin{array}{c}\text { Rectal cancer } v s \text { controls } \\
\text { OR }(95 \% \mathrm{CI})\end{array}$ & $P$ value \\
\hline$T / T$ & $51(52.58)$ & $29(36.25)$ & $7(38.89)$ & 1 (Reference) & & 1 (Reference) & \\
\hline $\mathrm{T} / \mathrm{C}$ & $43(44.33)$ & $43(53.75)$ & $8(44.44)$ & $1.78(0.96-3.31)$ & 0.0866 & $1.37(0.46-4.09)$ & 0.5901 \\
\hline $\mathrm{C} / \mathrm{C}$ & $3(3.09)$ & $8(10)$ & $3(16.67)$ & $4.87(1.19-19.80)$ & $0.0234^{*}$ & $7.57(1.27-45.07)$ & $0.0403 *$ \\
\hline Dom & $46(47.42)$ & $51(63.75)$ & $11(61.11)$ & $1.98(1.08-3.61)$ & $0.0347 *$ & $1.77(0.63-4.94)$ & 0.3131 \\
\hline Rec & $94(96.91)$ & $72(90)$ & $15(83.33)$ & $3.59(0.92-14.01)$ & 0.0639 & $6.46(1.19-35.05)$ & $0.0449 *$ \\
\hline Over-Dom & $54(55.67)$ & $37(46.25)$ & $10(55.55)$ & $1.39(0.77-2.53)$ & 0.2926 & $1.10(0.37-2.79)$ & 1.0000 \\
\hline
\end{tabular}

$\mathrm{OR}=$ odds ratio; $\mathrm{CI}=$ confidence intervals; Dom = dominant model $; \mathrm{Rec}=$ recessive model; Over-Dom = overdominant model; P values were calculated by the chi-square test. *Significant P values.

\section{DISCUSSION}

PPARD is the most widely expressed member of the PPAR ligand-activated transcription factor family in human cells. These receptors modulate many critical cellular functions, including fatty acid metabolism, wound healing, apoptosis, and inflammation. Therefore, PPARD could be involved in the development of several chronic diseases like diabetes (Villegas et al., 2011), cardiovascular disease (Skogsberg et al., 2003b; Lee et al., 2003), and cancer (Glinghammar et al., 2003; Peters et al., 2011; Ticha et al., 2013; Wang et al., 2014; Yang et al., 2014; Nath and Chan, 2016).

In this study, we investigated the influence of the $+294 \mathrm{~T} / \mathrm{C}$ (rs2016520) SNP of PPARD, a target of $\mathrm{Wnt} / \beta$-catenin signaling pathway, on genetic susceptibility to colorectal cancer in Mexican patients. Interestingly, our results revealed a decreased risk of CRC in patients bearing the heterozygous genotype T/C for the rs2016520 polymorphism. Moreover, this decreased cancer risk was evident under dominant and over-dominant models of inheritance.

Comparing the TNM stage I+II with III +IV, we did not find any statistically significant differences between them under any pattern of allelic interactions. However, when comparing the TNM stages I+II and III+IV with the control group, we observed a decreased cancer risk in patients bearing the heterozygous genotype T/C. In contrast, an increased risk was found for the TNM stage III+IV under the dominant model of inheritance and for the TNM stage I+II and III+IV under the over-dominant model of inheritance. Stratified analysis by tumor location revealed an increased cancer risk in patients with the homozygous genotype $\mathrm{C} / \mathrm{C}$, mainly for rectal cancer. This increased cancer risk was also observed under the dominant and recessive models of inheritance.

Recently, several studies have reported that PPARD is upregulated in human colorectal adenomas and cancers (Chen et al., 2004; Takami et al., 2007; Dong et al., 2009; Peters et al., 2011; Rennoll and Yochum, 2015). Barak et al. (2002) observed a non-statistically significant but reduced expression of PPARD and a decreased incidence of intestinal tumorigenesis in a knockout APC deleted mouse model (Hu et al., 2006). However, Harman et al. (2004) observed an increased incidence of intestinal tumorigenesis. In another study, Wang et al., (2006) found inhibition in intestinal tumorigenesis. In another study conducted by Zuo et al. (2014), a mouse model with targeted intestinal PPARD overexpression was used to clearly demonstrate the strong potential of PPARD overexpression in the enhancement of the colorectal tumorigenesis.

Although the majority of studies have addressed PPARD expression, some have examined genetic variants in the gene. These genetic variants have been found to be associated with regulation of lipid and glucose metabolism and disorders related to these processes.

Genetics and Molecular Research 16 (1): gmr16019324 
The study by Ticha et al. (2013) was the only study to include the analysis of the rs 2016520 polymorphism in order to determine its clinicopathological significance in colorectal cancer; the study results did not demonstrate any association between the rs2016520 SNP and colorectal cancer risk (Chen et al., 2004).

The role of rs2016520 polymorphism in PPARD in Mexican patients with colorectal cancer has not been investigated previously. Although the association between the rs2016520 polymorphism and cancer is presently unknown, the PPARD variants at 5'UTR are of particular interest owing to their hypothesized regulatory role in mRNA expression (Chen et al., 2004).

\section{CONCLUSION}

To our knowledge, this is the first study demonstrating a statistically significant association between the $+294 \mathrm{~T} / \mathrm{C}$ (rs2016520) polymorphism in PPARD and colorectal cancer in Mexican patients. The study results suggest that the T/C genotype has a protective role in susceptibility to CRC or an attenuating effect on colorectal carcinogenesis. Nevertheless, additional studies with larger sample sizes, more diverse populations, and that include a functional analysis of this polymorphism are necessary to confirm and extend our findings.

\section{Conflicts of interest}

The authors declare no conflict of interest.

\section{ACKNOWLEDGMENTS}

Research supported by grants from Fondo de Investigación en Salud, IMSS (FIS/ IMSS/PROT/G13/1228). M.A. Rosales-Reynoso is the recipient of a scholarship from Fundación IMSS, Mexico.

\section{REFERENCES}

Arnold CN, Goel A, Blum HE and Boland CR (2005). Molecular pathogenesis of colorectal cancer: implications for molecular diagnosis. Cancer 104: 2035-2047. http://dx.doi.org/10.1002/cncr.21462

Barak Y, Liao D, He W, Ong ES, et al. (2002). Effects of peroxisome proliferator-activated receptor delta on placentation, adiposity, and colorectal cancer. Proc. Natl. Acad. Sci. USA 99: 303-308. http://dx.doi.org/10.1073/pnas.012610299

Chen S, Tsybouleva N, Ballantyne CM, Gotto AM, Jr., et al. (2004). Effects of PPARalpha, gamma and delta haplotypes on plasma levels of lipids, severity and progression of coronary atherosclerosis and response to statin therapy in the lipoprotein coronary atherosclerosis study. Pharmacogenetics 14: 61-71. http://dx.doi.org/10.1097/00008571200401000-00007

Dong W, Shen R, Wang Q, Gao Y, et al. (2009). Sp1 upregulates expression of TRF2 and TRF2 inhibition reduces tumorigenesis in human colorectal carcinoma cells. Cancer Biol. Ther. 8: 2166-2174. http://dx.doi.org/10.4161/ cbt.8.22.9880

Fearon ER and Vogelstein B (1990). A genetic model for colorectal tumorigenesis. Cell 61: 759-767. http://dx.doi. org/10.1016/0092-8674(90)90186-I

Foreman JE, Chang WC, Palkar PS, Zhu B, et al. (2011). Functional characterization of peroxisome proliferator-activated receptor- $\beta / \delta$ expression in colon cancer. Mol. Carcinog. 50: 884-900. http://dx.doi.org/10.1002/mc.20757

Fucci A, Colangelo T, Votino C, Pancione M, et al. (2012). The role of peroxisome proliferator-activated receptors in the esophageal, gastric, and colorectal cancer. PPAR Res. 2012: 242498. http://dx.doi.org/10.1155/2012/242498

Gartel AL, Goufman E, Najmabadi F and Tyner AL (2000). Sp1 and Sp3 activate p21 (WAF1/CIP1) gene transcription in the Caco-2 colon adenocarcinoma cell line. Oncogene 19: 5182-5188. http://dx.doi.org/10.1038/sj.onc.1203900

Genetics and Molecular Research 16 (1): gmr16019324 
Glinghammar B, Skogsberg J, Hamsten A and Ehrenborg E (2003). PPARdelta activation induces COX-2 gene expression and cell proliferation in human hepatocellular carcinoma cells. Biochem. Biophys. Res. Commun. 308: 361-368. http://dx.doi.org/10.1016/S0006-291X(03)01384-6

Gupta RA, Wang D, Katkuri S, Wang H, et al. (2004). Activation of nuclear hormone receptor peroxisome proliferatoractivated receptor-delta accelerates intestinal adenoma growth. Nat. Med. 10: 245-247. http://dx.doi.org/10.1038/nm993

Harman FS, Nicol CJ, Marin HE, Ward JM, et al. (2004). Peroxisome proliferator-activated receptor-delta attenuates colon carcinogenesis. Nat. Med. 10: 481-483. http://dx.doi.org/10.1038/nm1026

He TC, Chan TA, Vogelstein B and Kinzler KW (1999). PPARdelta is an APC-regulated target of nonsteroidal antiinflammatory drugs. Cell 99: 335-345. http://dx.doi.org/10.1016/S0092-8674(00)81664-5

Hu C, Jia W, Fang Q, Zhang R, et al. (2006). Peroxisome proliferator-activated receptor (PPAR) delta genetic polymorphism and its association with insulin resistance index and fasting plasma glucose concentrations in Chinese subjects. Diabet. Med. 23: 1307-1312. http://dx.doi.org/10.1111/j.1464-5491.2006.02001.x

Jemal A, Bray F, Center MM, Ferlay J, et al. (2011). Global cancer statistics. CA Cancer J. Clin. 61: 69-90. http://dx.doi. org/10.3322/caac.20107

Krausova M and Korinek V (2014). Wnt signaling in adult intestinal stem cells and cancer. Cell. Signal. 26: 570-579. http://dx.doi.org/10.1016/j.cellsig.2013.11.032

Lee CH, Chawla A, Urbiztondo N, Liao D, et al. (2003). Transcriptional repression of atherogenic inflammation: modulation by PPARdelta. Science 302: 453-457. http://dx.doi.org/10.1126/science.1087344

Markowitz SD and Bertagnolli MM (2009). Molecular origins of cancer: Molecular basis of colorectal cancer. N. Engl. J. Med. 361: 2449-2460. http://dx.doi.org/10.1056/NEJMra0804588

Miller SA, Dykes DD and Polesky HF (1988). A simple salting out procedure for extracting DNA from human nucleated cells. Nucleic Acids Res. 16: 1215. http://dx.doi.org/10.1093/nar/16.3.1215

Nath A and Chan C (2016). Genetic alterations in fatty acid transport and metabolism genes are associated with metastatic progression and poor prognosis of human cancers. Sci. Rep. 6: 18669. http://dx.doi.org/10.1038/srep18669

Park BH, Vogelstein B and Kinzler KW (2001). Genetic disruption of PPARdelta decreases the tumorigenicity of human colon cancer cells. Proc. Natl. Acad. Sci. USA 98: 2598-2603. http://dx.doi.org/10.1073/pnas.051630998

Peters JM, Foreman JE and Gonzalez FJ (2011). Dissecting the role of peroxisome proliferator-activated receptor- $\beta / \delta$ (PPAR $/ \delta$ ) in colon, breast, and lung carcinogenesis. Cancer Metastasis Rev. 30: 619-640. http://dx.doi.org/10.1007/ $\underline{\text { s10555-011-9320-1 }}$

Raynaud CM, Jang SJ, Nuciforo P, Lantuejoul S, et al. (2008). Telomere shortening is correlated with the DNA damage response and telomeric protein down-regulation in colorectal preneoplastic lesions. Ann. Oncol. 19: 1875-1881. http://dx.doi.org/10.1093/annonc/mdn405

Rennoll S and Yochum G (2015). Regulation of MYC gene expression by aberrant Wnt/ $\beta$-catenin signaling in colorectal cancer. World J. Biol. Chem. 6: 290-300. http://dx.doi.org/10.4331/wjbc.v6.i4.290

Skogsberg J, Kannisto K, Cassel TN, Hamsten A, et al. (2003a). Evidence that peroxisome proliferator-activated receptor delta influences cholesterol metabolism in men. Arterioscler. Thromb. Vasc. Biol. 23: 637-643. http://dx.doi. org/10.1161/01.ATV.0000064383.88696.24

Skogsberg J, McMahon AD, Karpe F, Hamsten A, et al.; West of Scotland Coronary Prevention Study (2003b). Peroxisome proliferator activated receptor delta genotype in relation to cardiovascular risk factors and risk of coronary heart disease in hypercholesterolaemic men. J. Intern. Med. 254: 597-604. http://dx.doi.org/10.1111/j.1365-2796.2003.01236.x

Takami Y, Russell MB, Gao C, Mi Z, et al. (2007). Sp1 regulates osteopontin expression in SW480 human colon adenocarcinoma cells. Surgery 142: 163-169. http://dx.doi.org/10.1016/j.surg.2007.02.015

Ticha I, Gnosa S, Lindblom A, Liu T, et al. (2013). Variants of the PPARD gene and their clinicopathological significance in colorectal cancer. PLoS One 8: e83952. http://dx.doi.org/10.1371/journal.pone.0083952

Villegas R, Williams S, Gao Y, Cai Q, et al. (2011). Peroxisome proliferator-activated receptor delta (PPARD) genetic variation and type 2 diabetes in middle-aged Chinese women. Ann. Hum. Genet. 75: 621-629. http://dx.doi. org/10.1111/j.1469-1809.2011.00669.x

Wang D, Wang H, Guo Y, Ning W, et al. (2006). Crosstalk between peroxisome proliferator-activated receptor $\delta$ and VEGF stimulates cancer progression. Proc. Natl. Acad. Sci. USA 103: 19069-19074. http://dx.doi.org/10.1073/ pnas. 0607948103

Wang D, Fu L, Ning W, Guo L, et al. (2014). Peroxisome proliferator-activated receptor $\delta$ promotes colonic inflammation and tumor growth. Proc. Natl. Acad. Sci. USA 111: 7084-7089. http://dx.doi.org/10.1073/pnas.1324233111

Yang L, Zhou ZG, Luo HZ, Zhou B, et al. (2006). Quantitative analysis of PPARdelta mRNA by real-time RT-PCR in 86 rectal cancer tissues. Eur. J. Surg. Oncol. 32: 181-185. http://dx.doi.org/10.1016/j.ejso.2005.11.005

Genetics and Molecular Research 16 (1): gmr16019324 
Yang L, Zhou ZG, Zheng XL, Wang L, et al. (2008). RNA interference against peroxisome proliferator-activated receptor delta gene promotes proliferation of human colorectal cancer cells. Dis. Colon Rectum 51: 318-326, discussion 326328. http://dx.doi.org/10.1007/s10350-007-9145-8

Yang L, Olsson B, Pfeifer D, Jönsson JI, et al. (2010). Knockdown of peroxisome proliferator-activated receptor-beta induces less differentiation and enhances cell-fibronectin adhesion of colon cancer cells. Oncogene 29: 516-526. http://dx.doi.org/10.1038/onc.2009.370

Yang L, Zhang H, Zhou ZG, Yan H, et al. (2011). Biological function and prognostic significance of peroxisome proliferator-activated receptor $\delta$ in rectal cancer. Clin. Cancer Res. 17: 3760-3770. http://dx.doi.org/10.1158/10780432.CCR-10-2779

Yang Y, Burke RV, Jeon CY, Chang SC, et al. (2014). Polymorphisms of peroxisome proliferator-activated receptors and survival of lung cancer and upper aero-digestive tract cancers. Lung Cancer 85: 449-456. http://dx.doi.org/10.1016/j. lungcan.2014.06.014

Zhu GH, Lenzi M and Schwartz EL (2002). The Sp1 transcription factor contributes to the tumor necrosis factor-induced expression of the angiogenic factor thymidine phosphorylase in human colon carcinoma cells. Oncogene 21: 84778485. http://dx.doi.org/10.1038/sj.onc. 1206030

Zuo X, Peng Z, Moussalli MJ, Morris JS, et al. (2009). Targeted genetic disruption of peroxisome proliferator-activated receptor-delta and colonic tumorigenesis. J. Natl. Cancer Inst. 101: 762-767. http://dx.doi.org/10.1093/jnci/djp078

Zuo X, Xu M, Yu J, Wu Y, et al. (2014). Potentiation of colon cancer susceptibility in mice by colonic epithelial PPAR- $\delta / \beta$ overexpression. J. Natl. Cancer Inst. 106: dju052. http://dx.doi.org/10.1093/jnci/dju052

Genetics and Molecular Research 16 (1): gmr16019324 